\section{Variations in the Level of Lake George, Australia.}

ON May I8, I876, a letter appeared in NATURF from Canon $R$. Abbay on the subject of the changes in level of Lake George, in the south-east of New South Wales, which in the past hundred years has varied from a small swamp to a depth of 25 feet or more. We have now received from Cahon Abbay a letter and a diagram showing the variations of level in the lake from 1817 to 1918 . The latter, which is reproduced in Fig. $\mathrm{I}$, was drawn from information compiled by the late Mr. H. C. Russell, Government Astronomer of New South Wales, up to I904, and since that date by the Commonwealth Meteorological Bureau. It also shows the " residual rainfall curves" for Goulburn, the nearest station, and for Sydney, $15^{\circ}$ miles distant. A residual rainfall curve is obtained by finding the difference of rainfall for each year from the average for the whole period and adding up the differences for successive years, so that the figure plotted for any year represents the total excess or deficit of rainfall from the beginning of observations until that year. The curves show, as Canon Abbay points out, that while rainfall is
$\mathrm{L}$ (Actual level, inches from base) $=0.36 \mathrm{R}+0.36 \mathrm{~S}$.

The years in which the lake was dry have been omitted trom the calculations. The results confirm those obtained from Lake Victoria, that variations of evaporation are probably more important than rainfall variations in determining the level of lakes, and that the rate of evaporation is appreciably greater when sunspots are few than when they are numerous.

The diagram shows that the rairfall at Goulburn agrees fairly closely with that at Sydney, but if the rainfall at several stations over the lake basin had been available for a long period, there is no doubt that the correlation with their average would have been appreciably higher than that with Sydney rainfall. It also appears that the evaporation at Lake George is not determined by sunspots to the same extent as that at Lake Victoria. As Canon Abbay points out, the frequency of west and north-west winds would be of great importance in this connexion, and this would be governed by the pressure gradient between, say, Melbourne and Brisbane.

In 1875 Canon Abbay thought that the rise in the lake, which had proceeded fairly steadily from about I849 until that date, was connected with the destruction of "bush," allowing the rainfall to run

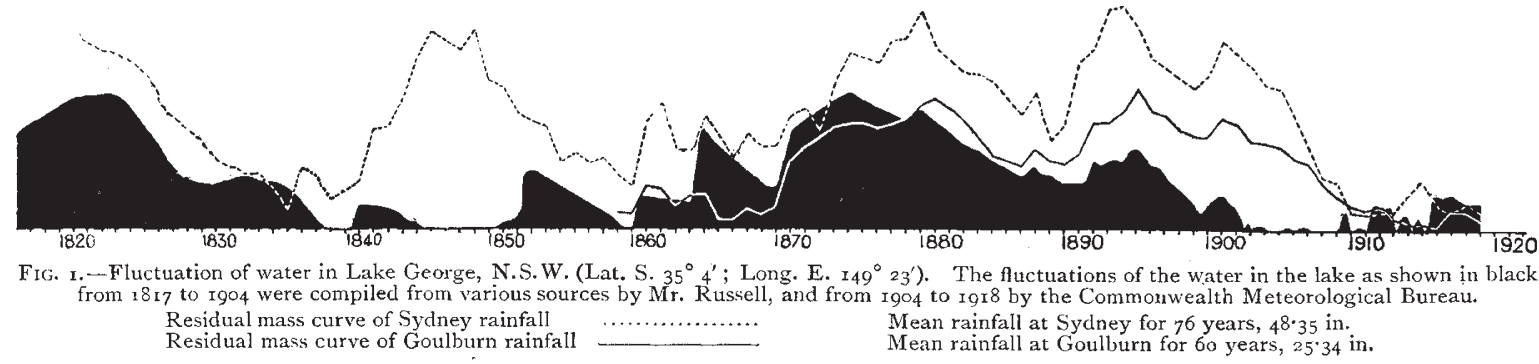

evidently an important factor in the level of the lake, there must also be other influences at work.

The lake is without outlet, and we may accordingly regard its changes of level as determined by the balance between the rainfall and evaporation in its basin, the loss by seepage probably being negligible. As a measure of rainfall the long series of observations at Sydney has been employed from the commencement of the official observations in 1840 . The question of evaporation is more difficult, but it has recently been found that in the Central African lakes, Victoria and Albert, the amount of evaporation bears a very close inverse relationship to the number of sunspots, the correlation coefficient between lake level (Lake Victoria) and sunspot number, after elimination of rainfall, being as high as +0.90 , and much higher than the correlation with the average rainfall in the basin. In the case of Lake George, a few years of heavy rainfall and slight evaporation result in a considerable rise of level, and if they were succeeded by a series of dry hot years the lake level would fall gradually until it was dry or until another wet period supervened. It was accordingly found best to correlate the changes in level between the beginning and the end of each year (L') with Sydney rainfall (R), and average sunspot number (S), during the same year, and the following results were obtained :

Correlation between change of level and rainfall; influence of sunspots eliminated : $r=+0 \cdot 35$.

Correlation between change of level and sunspots; influence of rainfall eliminated : $r=+0 \cdot 39$.

The regression equation is :

$\mathrm{L}^{\prime}$ (in inches) $=0.96 \mathrm{R}$ (in inches) $+0.43 \mathrm{~S}$ (Wolf's No.).

The corresponding equation for Lake Victoria, Central Africa, was:

into the basin with little loss, but the subsequent fall in level showed that this could not be the cause, since the destruction of the bush continued while the level of the lake was falling. The nineteen vear periodicity which has been advocated in connexion with Australian weather occurs in the lake levels, though not very definitely, and there is also an eleven-year periodicity connected with the sunspot effect. The two chief maxima in the level, about $\mathrm{I} 82 \mathrm{I}$ and $\mathrm{I} 875$, and the two chief periods when the lake was dry, about 1848 and 1905 , are separated by intervals of 54 to 57 years, and may represent a quasi-periodicity of about 56 years caused by the interference of these two periodicities; but weather cycles are treacherous things, and it would not be safe to base a forecast on them.

C. E. P. B.

\title{
Geological Progress in India.
}

$\mathrm{T}$. is satisfactory to notice that, in spite of financial stress in India, the Government has continued to add to the staff of the Geological Survey, which, with the recruits recently selected, now includes 26 out of the sanctioned 30 officers of the senior grade. The progress of work also during the last few years, since the return to normal duties of those officers who were on active service, has resulted in an approach to completion of many lines of work that had been for some time necessarily left indefinite. Among these the classification of the Tertiary beds of Burma, and their correlation with the Tertiaries of Western India and the standard stratigraphical scale of Europe, are now showing distinct signs of stability.

The untimely death of Mr. E. Vredenburg (NATURE, April I4, p. 505) prevents the completion of the heavy task of summarising the palæontological results, but 
the papers which he has published already, together with the work especially of Dr. G. de P. Cotter, are sufficient to permit of a satisfactory classification of the Burma Tertiaries, the correct correlation of which is of great importance to the petroleum industry of the province. Of the distinct steps forward, one of the most important has been recognition of the precise nature of the lateral variation in facies, especially that from north to south, in consequence of the progressive rise and silting of the meridional marine gulf which existed to the east of the Arakan hills in early Tertiary times. Extended mapping of the formations shows how freshwater formations in the north pass southwards into beds of marine origin, while estuarine and littoral beds pass into those of more settled marine origin. The papers of Messrs. Vredenburg and Cotter published in the Records of the Geological Survey (vols. li. and liv.) bring together the main results of this work expressed in tabular form, and additional details have just been issued in a posthumous paper by Mr. Vredenburg (vol. lv., part I, I923).

The correlation of the Burma Tertiaries with other areas has been based mainly on marine fossils, but, meanwhile, most valuable studies of the vertebrate remains included in freshwater beds have been carried on by Dr. G. E. Pilgrim. Most of this has been in connexion with the younger Tertiaries of the famous, but, as it proves, not entirely well-known, localities of the west and north-west. Recent work in the Punjab Salt Range shows that some revision of the correlation tables will be necessary, and that it will be possible, when the newly discovered vertebrate remains are studied, to correlate by direct fossil evidence the lower and middle Siwaliks of the Salt Range with those of the Himalayas.

The director's report of the Survey for I922, just issued by Dr. E. H. Pascoe in the Records, describes, besides a summary of Dr. Pilgrim's most recent work, some interesting results in other parts of India, in addition to those separately noticed in previous pages of NATURE. Among these, an interesting discovery of true Gondwana coal has been made in the Southern Shan States, indicating a Jurassic or Rhætic age, corresponding to a part of the upper division of the Gondwana system in India and some of the coal beds of Tonkin.

Considerable additions have also been made recently to our knowledge of the Deccan trap and of the dykes through which the lava attained the surface. Recent work by Mr. H. Walker in the Tapti valley reveals the interesting fact that the river, for more than 30 miles in an east-west line, follows a fault valley, roughly parallel to the general tendency to rifting which Sir Thomas Holland referred to in his presidential address to Section C (Geology) of the British Association at the meeting in Australia (Nature, vol. xciv., September 3, I9I4, p. 8) as a preparatory condition for the outflow of the Deccan lava sheets.

Another feature of general interest arises from the long-delayed analyses of brines from the Sambhar lake in Rajputana. The economic question which led to a special investigation of this lake 20 years ago arose from the observation of the salt-manufacturing officers that the lake showed signs of depleted resources and consequently possible loss as a source of Government revenue. The investigation undertaken in 1903 by the Geological Survey showed that, while the total amount of sodium chloride stored in the silt rendered nervousness on this account unnecessary, there was a possibility that the continual removal of pure chloride as salt and the consequent increase in the proportion of residual carbonate and sulphate among the soluble salts might increase the difficulty of customary manufacture by fractional crystallisation. A methodical system of sampling was then undertaken annually from various parts of the lake, and Dr. W. A. K. Christie has recently analysed the products. A summary of his results shows that there was a small but definite deterioration in chloride as the result of ten years' work in extracting salt between I907 and I9I6. Taking the two five-year periods to tone out annual variations, the ratio of chloride to other soluble salts in the lake brine has dropped from 86.09: I3.9I to $85^{\circ} 3^{8}: \mathbf{I}_{4} \cdot 62$. In the brines obtained from the sublacustrine silt the corresponding ratio has fallen from $83.18: 16.82$ to $81.07: 18.93$. Arrangements have been made for resuming the annual sampling of the brines; for unless a system be devised for recovering some of the other salts, the value of the lake as a source of salt will cease long before there is any approach to exhaustion of the total supplies.

\section{Palæontology at the American Museum of Natural History.}

THE researches of the palæontological department of the American Museum of Natural History for the years 1918 to I92 I have now been issued as a volume, making the seventh in the series. In all there are twenty-three papers, contributed by Prof. H. F. Osborn, Dr. Matthew, Dr. Gregory, Messrs. Granger, Mook, Von Huene, Miller, Gidley, and Camp. Prof. Osborn describes some new Titanotheres, mostly primitive forms, from the Huerfano, and in two other papers continues his studies on the Proboscidea. One is an account of some American mastodons, and the other is important as giving his views to date on the evolution, phylogeny, and classification of the elephant group as a whole. Dr. Matthew, in addition to faunistic papers, continues, with Mr. Granger, the review of the faunas of the Eocene deposits of the United States. The papers by Messrs. Gidley and Miller are faunistic. There is a series of ten papers by Mr. Mook on crocodiles, recent and extinct; a paper by Mr. Von Huene on reptilian and stegocephalian remains in the Cope collection; and three by Dr. W. K. Gregory, one of them in collaboration with Mr. Camp, which are continuations of his studies on the comparative myology and osteology of vertebrates.

In considering these contributions to our knowledge of palæontology, for the value of which the authors' names are a sufficient guarantee, it will be noticed that the bulk of them are continuations of previous studies, and are designed to attack definite problems. Such, for example, is the series by Dr. Gregory on the muscles and bones, where various parts are compared one by one and worked out in a most systematic manner. These papers will form a mine for other workers. In the same spirit is Mr. Mook's intensive study of the crocodiles and Prof. Osborn's on the elephants.

The volume is a worthy memorial to the energy and devotion of the president and staff of the museum, and the museum without doubt gains from this advertisement of its activity. If the publications by members of the staff of the palæontological department of the British Museum for a similar period were gathered together, it is probable that they would make a worthy companion volume, but, being widely scattered in several publications, the public has never the opportunity to discover this fact.

It may further be noted that, in the period covered by these communications, the American Museum from its palæontological department alone sent six expeditions into the field as far as China, India, and Cuba, as well as in the States themselves.

$$
\text { NO. } 2825 \text {, VOL. [I } 2 \text { ] }
$$

